\title{
Class II one-peptide bacteriocins target a phylogenetically defined subgroup of mannose phosphotransferase systems on sensitive cells
}

\author{
Correspondence \\ Dzung B. Diep \\ dzung.diep@umb.no
}

$\begin{array}{ll}\text { Received } & 15 \text { April } 2009 \\ \text { Revised } & 26 \text { May } 2009 \\ \text { Accepted } 27 \text { May } 2009\end{array}$

\author{
Morten Kjos, Ingolf F. Nes and Dzung B. Diep \\ Department of Chemistry, Biotechnology and Food Science, Norwegian University of Life Sciences, \\ PO Box 5003, 1432 Ås, Norway
}

\begin{abstract}
Membrane-located proteins (IIC and IID) of the mannose-phosphotransferase system (man-PTS) have previously been shown to serve as target receptors for several bacteriocins. Although many bacteria contain at least one such man-PTS in their genome, most bacteriocins display a narrow inhibitory spectrum, targeting predominantly bacteria closely related to the producers. In the present study we have analysed the receptor spectrum of one-peptide bacteriocins of class II. A phylogenetic analysis of 86 man-PTSs from a wide range of bacterial genera grouped the manPTSs into three main clusters (groups I-III). Fourteen man-PTSs distributed across the phylogenetic tree were selected for experimental analysis in a heterologous host. Only members of group I could serve as receptors for class lla bacteriocins, and the receptor efficiencies varied in a pattern directly related to their phylogenetic position. A multiple sequence alignment of IIC and IID proteins revealed three sequence regions (two in IIC and one in IID) that distinguish members of the bacteriocin-susceptible group from those of the other groups, suggesting that these amino acid regions confer the specific bacteriocin receptor function. Moreover, we demonstrated that variation in sensitivity might also exist within the same species due to differential expression levels of the receptor, since three strains of Lactobacillus sakei harbouring identical man-PTSs were shown to display different expression levels of a man-PTS gene that corresponded to the variation in bacteriocin sensitivity. Together, the results of our study show that the level of bacteriocin susceptibility for a bacterial cell is primarily determined by differences in its man-PTS proteins, although the expression levels of the corresponding genes also play an important role.
\end{abstract}

\section{INTRODUCTION}

Bacteriocins are ribosomally synthesized antimicrobial peptides produced by a wide range of Gram-positive bacteria, of which lactic acid bacteria (LAB) constitute the major part. Most of these antimicrobial substances direct their activity toward bacteria closely related to the producers, but some also have broader inhibitory spectra, including important pathogens such as the food-borne Listeria monocytogenes and pathogenic species of Enterococcus. The LAB bacteriocins are classified into two major classes (Nes et al., 2007): the class I lantibiotics, containing post-translationally modified amino acids such as lanthionine, dehydrated amino acids and thioether

Abbreviations: aLRT, approximate likelihood-ratio test; BU, bacteriocin unit; 2-DG, 2-deoxy-D-glucose; man-PTS, mannose-phosphotransferase system.

A supplementary figure, showing a multiple sequence alignment of all 86 man-PTSs used in the phylogenetic analysis, and a supplementary table, listing man-PTSs used in the phylogenetic analysis, are available with the online version of this paper. cross-linked amino acids; and the class II non-lantibiotics, containing only non-modified amino acids. The class II bacteriocins are further categorized into several subgroups. The subclass IIa bacteriocins have a conserved sequence (YGNG[V/L]) and a disulfide bridge in their N-terminal region and are known for their strong anti-listerial activity (Nissen-Meyer et al., 2009); these peptides are normally referred to as pediocin-like bacteriocins after pediocin PA1 , the first member characterized from this subclass (Henderson et al., 1992; Nieto Lozano et al., 1992). Subclass IIb contains bacteriocins whose full activity is dependent on the complementary action of two different peptides (e.g. lactococcin G and plantaricin EF and JK), and subclass IId contains bacteriocins without leader sequences (e.g. enterocin L50 and lacticin Q). Finally, the bacteriocins that do not belong to any of the above subgroups (e.g. lactococcin A and B) are placed in class IIc (Nes et al., 1996, 2007).

Most bacteriocins are believed to kill sensitive cells by disrupting the integrity of target membranes, which leads 
to dissipation of the proton motive force, depletion of intracellular solutes, and eventually cell death (Drider et al., 2006). The fact that each bacteriocin displays a defined inhibitory spectrum strongly suggests that the individual bacteriocins recognize specific receptor molecules on target cells. In fact, it has been shown that several of the class I lantibiotics as well as the non-lantibiotic lactococcin 972 employ lipid II, a precursor in cell wall synthesis, as a docking molecule, and interaction between a bacteriocin and lipid II leads to inhibition of cell wall synthesis and/or pore formation, depending on the structure of the bacteriocin and its concentration (Brotz et al., 1998; Martinez et al., 2008; Wiedemann et al., 2001). Similarly, some studies have shown that the mannose-phosphotransferase system (man-PTS) might serve as a receptor for some pediocin-like bacteriocins, based on the observations that resistant mutants have an altered expression pattern of man-PTS and that heterologous expression of cloned manPTS genes renders resistant cells sensitive (Dalet et al., 2001; Gravesen et al., 2002; Héchard et al., 2001; Ramnath et al., 2000, 2004). More recently, it has been conclusively demonstrated for several bacteriocins from subclass IIa and some from subclass IIc that the membrane components (ManM/PtnC and ManN/PtnD) of the man-PTS are directly involved as receptors, and that in bacteriocinproducing cells, a cognate immunity protein tightly binds the receptor in a bacteriocin-dependent manner, to prevent killing by the bacteriocin (Diep et al., 2007).

The man-PTS transporter family is responsible for the concomitant import and phosphorylation of carbohydrates such as mannose and glucose in bacteria (Postma et al., 1993). A PTS transporter normally consists of three major components: enzyme I (EI), HPr and enzyme II (EII). The first two are cytoplasmic proteins involved in the transfer of a phosphoryl group to EII, which in turn relays the phosphoryl group to imported sugar molecules. EI and HPr serve as common phosphoryl group suppliers for different EIIs, while the individual EIIs are specific for each PTS family and are responsible for the sugar specificity. EII in man-PTS consists of four subunits, IIA, IIB, IIC and IID, in which the first two appear as one single (IIAB) or two separate (IIA and IIB) proteins, and the last two (IIC and IID) normally are separate proteins. Subunits IIA and IIB are located in the cytoplasm, while IIC and IID together form a membrane-located complex through which the sugar entities enter the cell (Postma et al., 1993). Expression of the genes encoding these four subunits is coordinated, as they are commonly clustered in one operon (Deutscher et al., 2006).

Hitherto, a few reports have linked sensitivity to class IIa bacteriocins to specific man-PTSs. For instance, the $m p t$ operons in Enterococcus faecalis V583 and Li. monocytogenes EGD-e have been shown to be required for sensitivity to mesentericin Y105 (Dalet et al., 2001; Héchard et al., 2001). Another man-PTS of Li. monocytogenes EGD-e, encoded by the mpo operon, has also been shown to be involved in sensitivity to class IIa bacteriocins via regulation of the mpt operon (Arous et al., 2004). Furthermore, in a recent study of bacteriocin sensitivity and immunity in our laboratory (Diep et al., 2007), it was shown that the man operon of Lactobacillus sakei $23 \mathrm{~K}$ confers sensitivity to a number of class IIa bacteriocins, while the ptn operon of Lactococcus lactis IL1403 confers sensitivity to the class IIc bacteriocins lactococcin A and lactococcin B. However, for several bacteria of both bacteriocin-sensitive and non-sensitive species, a large number of homologous putative man-PTS transporter genes are found in the genomes (Zúñiga et al., 2005) and whether these homologous man-PTS proteins can serve as receptors for bacteriocins has not been evaluated. Starting from a bioinformatics approach, we systematically selected a number of man-PTSs from different genera, and showed that only a defined phylogenetic group of the man-PTSs confers sensitivity to class IIa bacteriocins and, more importantly, that variation in bacteriocin sensitivity can, to a large extent, be predicted on the basis of man-PTS phylogenetic positions.

\section{METHODS}

Phylogenetic analysis. To screen for man-PTS proteins in databases, the proteins ManM (YP_395063) and ManN (YP_395064) from $L b$. sakei $23 \mathrm{~K}$ were used as query sequences; these two proteins are members of the conserved IIC and IID protein families. Amino acid sequences of man-PTS proteins were retrieved from the Entrez Gene database (http://www.ncbi.nlm.nih.gov/sites/entrez?db=gene) using the Basic Local Alignment Search Tool (BLASTP; http://www.ncbi.nlm.nih.gov/blast/Blast.cgi) with standard settings. All PTS transporters selected for further study, as listed in Supplementary Table S1, have been classified as man-PTSs (Zúñiga et al., 2005). Phylogenetic analysis was performed using the web service Phylogeny.fr (http://www.phylogeny.fr; Dereeper et al., 2008): Sequences were aligned using MUSCLE v3.7 (Edgar, 2004) in default mode. The phylogenetic tree was constructed with the maximum-likelihood algorithm implemented in PhyML v3.0 (Guindon \& Gascuel, 2003) with the following settings: (i) initial tree: BIONJ; (ii) amino acid substitution model: WAG; (iii) proportion of invariant sites: estimated; (iv) number of substitution rate categories: 4; (v) gamma shape parameter: estimated. The reliability of the branches was assessed using bootstrap analysis with 100 replicates and an approximate likelihood-ratio test (aLRT) (Anisimova \& Gascuel, 2006) with the Shimodaira-Hasegawa-like (non-parametric) procedure. The phylogenetic trees were visualized using TreeDyn (Chevenet et al., 2006).

Bacterial strains and growth conditions. The bacterial strains used in this study are listed in Table 1. Lc. lactis IL1403 and clones derived therefrom were routinely grown at $30{ }^{\circ} \mathrm{C}$ in M17 medium (Oxoid) supplemented with $0.4 \%(\mathrm{w} / \mathrm{v})$ glucose or $0.4 \%(\mathrm{w} / \mathrm{v})$ galactose, Lactobacillus plantarum WCFS1 and Lactobacillus delbrueckii ATCC 11842 in MRS medium (Oxoid) at 30 and $37^{\circ} \mathrm{C}$, respectively, Li. monocytogenes EGD-e and Ent. faecalis V583 in BHI medium (Oxoid) at $37^{\circ} \mathrm{C}$, Streptococcus thermophilus LMG 18311 in Todd-Hewitt broth (BD) supplemented with $0.8 \%(\mathrm{w} / \mathrm{v})$ glucose and Escherichia coli in LB medium (Oxoid) at $37{ }^{\circ} \mathrm{C}$ with agitation (250 r.p.m.). When appropriate, erythromycin $\left(5 \mu \mathrm{g} \mathrm{ml}^{-1}\right)$ and chloramphenicol $\left(5 \mu \mathrm{g} \mathrm{ml}^{-1}\right)$ were added to the growth medium. Growth analysis was performed using Bioscreen C (Oy Growth Curves); overnight cultures were diluted 100 -fold, and $\mathrm{OD}_{600}$ was measured at intervals of $20 \mathrm{~min}$. 
Table 1. Plasmids and bacterial strains used in this study

\begin{tabular}{|c|c|c|}
\hline Plasmid or strain & Characteristics $^{\star} \dagger$ & Reference or source \\
\hline \multicolumn{3}{|l|}{ Plasmids } \\
\hline pNZ9530 & Vector expressing nisRK (nisin regulatory genes), EryR & Kleerebezem et al. (1997) \\
\hline p513 & pNZ8037 with man-PTS Lsak ( $m a n L$, manM, manN) of Lb. sakei LMGT2313 & This study \\
\hline p515 & pNZ8037 with man-PTS Lsak (manL, manM, manN) of Lb. sakei $23 \mathrm{~K}$ & Diep et al. (2007) \\
\hline p517 & pNZ8037 with man-PTS Lsak (manL, manM, manN) of Lb. sakei Lb790 & This study \\
\hline pEcoll & pNZ8037 with man-PTS Ecoll (agaB, agaC, agaD) of E. coli BL21 & This study \\
\hline pEcol2 & pNZ8037 with man-PTS Ecol2 ( $\operatorname{manX}, \operatorname{man} Y, \operatorname{manZ})$ of E. coli BL21 & This study \\
\hline pEfael & $\begin{array}{l}\text { pNZ8037 with man-PTS Efae1 (EF0020, EF0021, EF0022) of Ent. faecalis } \\
\text { V583 }\end{array}$ & This study \\
\hline pEfae12 & $\begin{array}{l}\text { pNZ8037 with man-PTS Efae12 (EF3136, EF3137, EF3138, EF3139) of } \\
\text { Ent. faecalis V583 }\end{array}$ & This study \\
\hline pLmon2 & $\begin{array}{l}\text { pNZ8037 with man-PTS Lmon2 (lmo0021, lmo0022, lmo0023, lmo0024) of } \\
\text { Li. monocytogenes EGD-e }\end{array}$ & This study \\
\hline pLmon3 & $\begin{array}{l}\text { pNZ8037 with man-PTS Lmon3 (lmo1997, lmo2000, lmo2001, lmo2003) of } \\
\text { Li. monocytogenes EGD-e }\end{array}$ & This study \\
\hline pLmon4 & $\begin{array}{l}\text { pNZ8037 with man-PTS Lmon4 (lmo0096, Imo0097, lmo0098) of } \\
\text { Li. monocytogenes EGD-e }\end{array}$ & This study \\
\hline pLpla1 & $\begin{array}{l}\text { pNZ8037 with man-PTS Lpla2 ( } p t s 9 A, p t s 9 B, p t s 9 C, p t s 9 D) \text { of } \\
\text { Lb. plantarum WCFS1 }\end{array}$ & This study \\
\hline pLpla2 & $\begin{array}{l}\text { pNZ8037 with man-PTS Lpla2 (pts19A, pts19D, pts19C, pts19B) of } \\
\text { Lb. plantarum WCFS1 }\end{array}$ & This study \\
\hline pSthe & $\begin{array}{l}\text { pNZ8037 with man-PTS Sthe ( } \operatorname{manL}, \operatorname{man} M, \operatorname{manN} \text { ) of S. thermophilus } \\
\text { LMG18311 }\end{array}$ & This study \\
\hline Lb. plantarum WCFS1 & Source of man-PTS & Kleerebezem et al. (2003) \\
\hline \multicolumn{3}{|l|}{ Lb. sakei } \\
\hline B316 & Lb. sakei Lb790 clone producing penocin A & Diep et al. (2006) \\
\hline B317 & Lb. sakei Lb790 clone producing sakacin A & Diep et al. (2006) \\
\hline LTH673 & Sakacin $\mathrm{P}$ producer & Tichaczek et al. (1992) \\
\hline Lb790 & Source of man-PTS & Schillinger \& Lucke (1989) \\
\hline $23 \mathrm{~K}$ & Source of man-PTS & Lauret et al. (1996) \\
\hline LMGT 2313 & Source of man-PTS & LMGT strain collection \\
\hline \multicolumn{3}{|l|}{ Lc. lactis } \\
\hline IL1403 & Indicator strain for lactococcin A & Chopin et al. (1984) \\
\hline B488 & ptn deletion mutant of Lc. lactis IL1403 carrying pNZ9530 with nisRK, EryR & Diep et al. (2007) \\
\hline B515 & B488 with p423, CamR, EryR & Diep et al. (2007) \\
\hline B520 & B488 with pNZ8037, CamR, EryR & Diep et al. (2007) \\
\hline B628 & B488 with p513, CamR, EryR & This study \\
\hline B630 & B488 with p515, CamR, EryR & Diep et al. (2007) \\
\hline B632 & B488 with p517, CamR, EryR & This study \\
\hline M127 & B488 with pLpla1, CamR, EryR & This study \\
\hline M128 & B488 with pLpla2, CamR, EryR & This study \\
\hline M129 & B488 with pEcoll, CamR, EryR & This study \\
\hline M130 & B488 with pEcol2, CamR, EryR & This study \\
\hline M148 & B488 with pLmon1, CamR, EryR & This study \\
\hline M149 & B488 with pLmon2, CamR, EryR & This study \\
\hline
\end{tabular}


Table 1. cont.

\begin{tabular}{|c|c|c|}
\hline Plasmid or strain & Characteristics $^{\star} \dagger$ & Reference or source \\
\hline M150 & B488 with pLmon3, CamR, EryR & This study \\
\hline M151 & B488 with pLmon4, CamR, EryR & This study \\
\hline M158 & B488 with pSthe, CamR, EryR & This study \\
\hline M159 & B488 with pLdel, CamR, EryR & This study \\
\hline M160 & B488 with pEfae1, CamR, EryR & This study \\
\hline M161 & B488 with pEfae12, CamR, EryR & This study \\
\hline Li. іппосиа LMGT 2785 & Indicator strain for class IIa bacteriocins & LMGT strain collection \\
\hline Li. monocytogenes EGD-e & Source of man-PTSs & Glaser et al. (2001) \\
\hline Pediococcus acidilactici PAC 1.0 & Pediocin PA-1 producer & Henderson et al. (1992) \\
\hline S. thermophilus LMG 18311 & Source of man-PTS & Bolotin et al. (2004) \\
\hline
\end{tabular}

${ }^{\star}$ EryR, erythromycin resistance; CamR, chloramphenicol resistance.

$\dagger$ Locus tags of the man-PTS genes are given in parentheses. Protein accession numbers are given in Supplementary Table S1.

‡Laboratory of Microbial Gene Technology, Ås, Norway.

Genetic cloning. The constructs used in this study are listed in Table 1. Man-PTS genes from different strains were amplified by PCR, using the primers listed in Table 2. Total genomic DNA from the respective strains was used as template in all PCRs. The PCR products were cleaved with SphI and XhoI, except Lmon3, which was cleaved with SphI and SalI (all restriction endonucleases from New England Biolabs), and ligated into the nisin-regulated pNZ8037-derivative plasmid p519 (Diep et al., 2007) between the SphI and XhoI sites, resulting in the plasmids listed in Table 1 . All cloned genes were confirmed by sequencing. Transformation into the man-PTS-free strain Lc. lactis B488 (Diep et al., 2007) was performed using the electroporation protocol of Holo \& Nes (1989).

RNA isolation, cDNA synthesis and RT-PCR. RT-PCR was performed on three strains of $L b$. sakei (23K, Lb790 and LMGT 2313). Cells in exponential growth $\left(\mathrm{OD}_{600} \sim 0.5\right)$ were harvested by centrifugation and stored at $-80{ }^{\circ} \mathrm{C}$. The cell pellet was dissolved in $700 \mu \mathrm{l}$ buffer RTL (Qiagen) supplemented with $0.1 \%(\mathrm{v} / \mathrm{v}) \quad \beta$ mercaptoethanol (Sigma), and the suspension was transferred to $2 \mathrm{ml}$ screw-capped FastPrep tubes (MP Biomedicals) containing $0.5 \mathrm{~g}$ acid-washed glass beads ( $<106 \mu \mathrm{m}$, Sigma), $300 \mu \mathrm{l}$ phenol and $300 \mu \mathrm{l}$ chloroform. Cells were lysed using Fp120 Fastprep (Bio 101) for three times $25 \mathrm{~s}$ at $4 \mathrm{~m} \mathrm{~s}^{-1}$ at $4{ }^{\circ} \mathrm{C}$. Following a short centrifugation (10 $000 \mathrm{~g}$ for $1 \mathrm{~min}$ ), the water phase was transferred to a fresh Eppendorf tube containing $500 \mu \mathrm{l}$ ethanol. The lysate was then applied to RNeasy spin columns (Qiagen), and RNA was purified as described by the manufacturer (Qiagen). To remove remnants of DNA, RNA was treated with RNase-free DNase I (Qiagen). cDNA was synthesized using the Superscript III Reverse Transcriptase set (Invitrogen), and RNA was then removed by treatment with RNase H (Takara Bio). RTPCR was carried out using primers mk86 (5'-CCATGTCTTATCTTAGGCGG-3') and mk87 (5'-ACCATCTGTTAACCATACTGG$3^{\prime}$ ) for manM (encoding the IIC subunit), and mk96 (5'-CGTGCTTCCATACCTTCAAC-3') and mk97 (5'-ACCTCAAGTTGCTTACCGTG- $3^{\prime}$ ) for the housekeeping gene fusA (encoding translation elongation factor EF-G). Primers were designed based on the annotated genome sequence of Lb. sakei 23K (Chaillou et al., 2005).

Bacteriocin assays. Bacteriocins (pediocin PA-1, enterocin $\mathrm{P}$, sakacin $\mathrm{P}$, penocin $\mathrm{A}$ and lactococcin $\mathrm{A}$ ) were concentrated from supernatants of overnight cultures by ammonium sulphate precipitation as described previously (Diep et al., 2007). The bacteriocin activity in the concentrated supernatants was determined using Listeria innocua LMGT 2785 and Lc. lactis IL1403 as indicator strains for class IIa bacteriocins and lactococcin A, respectively. Bacteriocin sensitivity of the different $L c$. lactis clones was determined using a microtitre plate assay. Overnight cultures were diluted 100-fold in a medium containing $0.1 \mathrm{ng}$ nisin $\mathrm{ml}^{-1}$ to induce expression of the cloned genes, and growth inhibition was measured spectrophotometrically at $600 \mathrm{~nm}$ after $15-18 \mathrm{~h}$. One bacteriocin unit (BU) was defined as the amount of bacteriocin required to produce $50 \%$ growth inhibition in a $200 \mu \mathrm{l}$ culture of the indicator strain. MIC was defined as the minimum bacteriocin concentration needed to produce at least $50 \%$ growth inhibition of tested clones.

\section{RESULTS AND DISCUSSION}

\section{Bioinformatic analysis of man-PTS family proteins}

A large number of homologous man-PTS genes are found in the genome sequences of different bacterial species (Zúñiga et al., 2005). To get an overview of different members of the man-PTS family in the context of being a reservoir of potential bacteriocin receptors, we first analysed these proteins with a phylogenetic approach. We chose to focus only on the membrane-located subunits (IIC and IID), because expression of these genes (without IIAB) has previously been shown to be sufficient to confer sensitivity to several class IIa bacteriocins and class IIc lactococcins A and B (Diep et al., 2007). By using the proteins ManM (IIC) and ManN (IID) from Lb. sakei $23 \mathrm{~K}$ as query sequences, a large number of homologous manPTS IIC and IID protein sequences were retrieved from the Entrez Gene database (sequence identity ranging from 84 to $22 \%$ ) using BLAST. Members of the man-PTS family were found predominantly in species belonging to two separate phylogenetic taxa, the Gram-positive Firmicutes and the Gram-negative Proteobacteria. This observation is in line with the evolutionary analysis of man-PTS transporters of Zúñiga et al. (2005), who propose that these transporters have been distributed to species of Firmicutes and Proteobacteria by horizontal gene transfer. The in silico analysis of published genomes revealed that 
Table 2. Primers used in this study

\begin{tabular}{|c|c|c|}
\hline $\begin{array}{l}\text { Amplified } \\
\text { product }\end{array}$ & Primer & Sequence $\left(5^{\prime} \rightarrow 3^{\prime}\right)$; restriction site se $^{*}$ \\
\hline Lpla1 & mk54 & AGCTGCATGCCACTGTAACGAAAAATAGGAGG; SphI \\
\hline \multirow[t]{2}{*}{ Lpla2 } & $\mathrm{mk} 53$ & ACGTGCATGCCGTAGGTTAATTACTATCCGC; SphI \\
\hline & $\mathrm{mk} 48$ & ATGCCTCGAGCAACAGATAACTTGTTAATCGG; XhoI \\
\hline Ecoll & $\mathrm{mk} 49$ & ACGTGCATGCAGTGCCTTAATGGAAAAGGAG; SphI \\
\hline \multirow[t]{2}{*}{ Ecol2 } & mk51 & 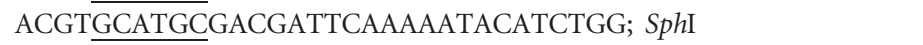 \\
\hline & $\mathrm{mk} 52$ & ATCGCTCGAGGCCAAAAGGCCCCGGTAG; XhoI \\
\hline \multirow[t]{2}{*}{ Lmon 1} & mk56 & 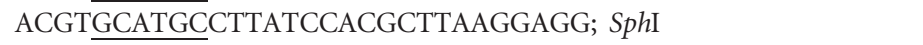 \\
\hline & $\mathrm{mk} 57$ & ATGCCTCGAGAGAACCGGAATTTTAATCCCG; XhoI \\
\hline \multirow[t]{2}{*}{ Lmon2 } & $\mathrm{mk} 58$ & 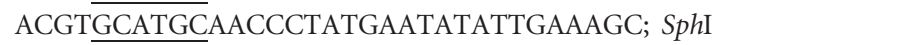 \\
\hline & mk59 & ATCGCTCGAGACCCATTTTGTCTATTCCTCC; XhoI \\
\hline \multirow[t]{2}{*}{ Lmon 4} & mk64 & ACGTGCATGCGCAATAAATATAGCGGGTAGC; SphI \\
\hline & mk65 & 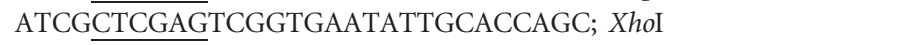 \\
\hline \multirow[t]{2}{*}{ Sthe } & mk72 & 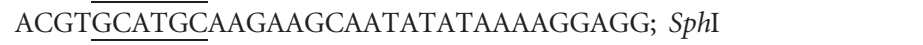 \\
\hline & $\mathrm{mk} 73$ & 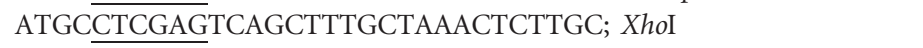 \\
\hline \multirow[t]{2}{*}{ Ldel } & $\mathrm{mk} 74$ & ACGTGCATGCTACCGAAGTTTTTGAGGAGG; SphI \\
\hline & mk75 & ATGCCTCGAGACGGTCTTATTCATTGATTGAG; XhoI \\
\hline \multirow[t]{2}{*}{ Efael } & mk76 & 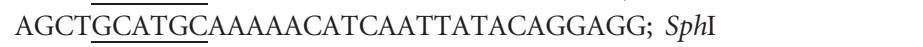 \\
\hline & mk77 & ATGCCTCGAGTTGATTAGAAGTAATAAACTTACC; XhoI \\
\hline \multirow[t]{2}{*}{ Efae12 } & $\mathrm{mk} 80$ & AGCTGCATGCCCAAAACCAAGGATAAGAAGG; $S p h I$ \\
\hline & $\mathrm{mk} 81$ & ATGCCTCGAGTCCCCATTTCATTGCTTTCAC; XhoI \\
\hline Lsak & pr205 & CATTATAATTGCATGCGTTTTTATCAGTGTG; SphI \\
\hline
\end{tabular}

${ }^{*}$ Restriction sites are underlined in the sequences.

$\dagger$ In Lmon3, the gene encoding the IIA subunit is separated from the other genes by $2112 \mathrm{bp}$. To remove this sequence, Lmon3 was amplified using a two-step PCR approach (Higuchi, 1990), with mk60 and mk62 as outer primers and mk61 and mk63 as inner primers.

the number of different man-PTSs within a strain is highly variable between different genera, e.g. only one is found in $L c$. lactis, Lb. sakei and S. thermophilus, four in $L i$. monocytogenes and a total of 13 in Ent. faecalis V583. Some of the man-PTS operons are incomplete, i.e. missing one or two of the four subunits (e.g. the agaBCD operon in E. coli, encoding IIB, IIC and IID, but no IIA subunit). Based on an initial phylogenetic clustering of all collected sequences, 86 man-PTSs from the Entrez Gene database were selected for further phylogenetic analysis, and the man-PTSs were designated using the following four-letter system: the first letter was derived from the first letter of the genus name, the next three from the first three letters in the species name, and a digit when more than one manPTS was present in the bacterial species, e.g. Lmon1 for one of the man-PTSs from Li. monocytogenes (an overview of the proteins used in the phylogenetic analysis can be found in Supplementary Table S1). The phylogenetic trees of protein families IIC and IID (Fig. 1) show that their members are clustered into three distinct groups in both families, named groups I, II and III, and this grouping is supported by significant branch support values (bootstrap value $>0.85$, aLRT value $>0.9$ ). Group III is the largest and most diverse. In all cases, the phylogenetic position of a IIC protein and its cognate IID protein (from the same manPTS) correspond well with each other, i.e. both occupy a similar position in their respective trees, suggesting that the pairwise IIC and IID subunits have evolved in parallel. Notably, we observed that the man-PTSs previously suggested to be involved as receptors for class IIa bacteriocins Efael (mpt operon from Ent. faecalis; Héchard et al., 2001), Lmon4 (mpt operon from Li. monocytogenes; Dalet et al., 2001) and Lsak (man operon from Lb. sakei; Diep et al., 2007) are clustered in group I.

\section{Class Ila and IIc bacteriocins target only a phylogenetically defined subset of man-PTSs}

To evaluate which man-PTSs from different loci or different bacteria act as receptors for bacteriocins of class 
(a)
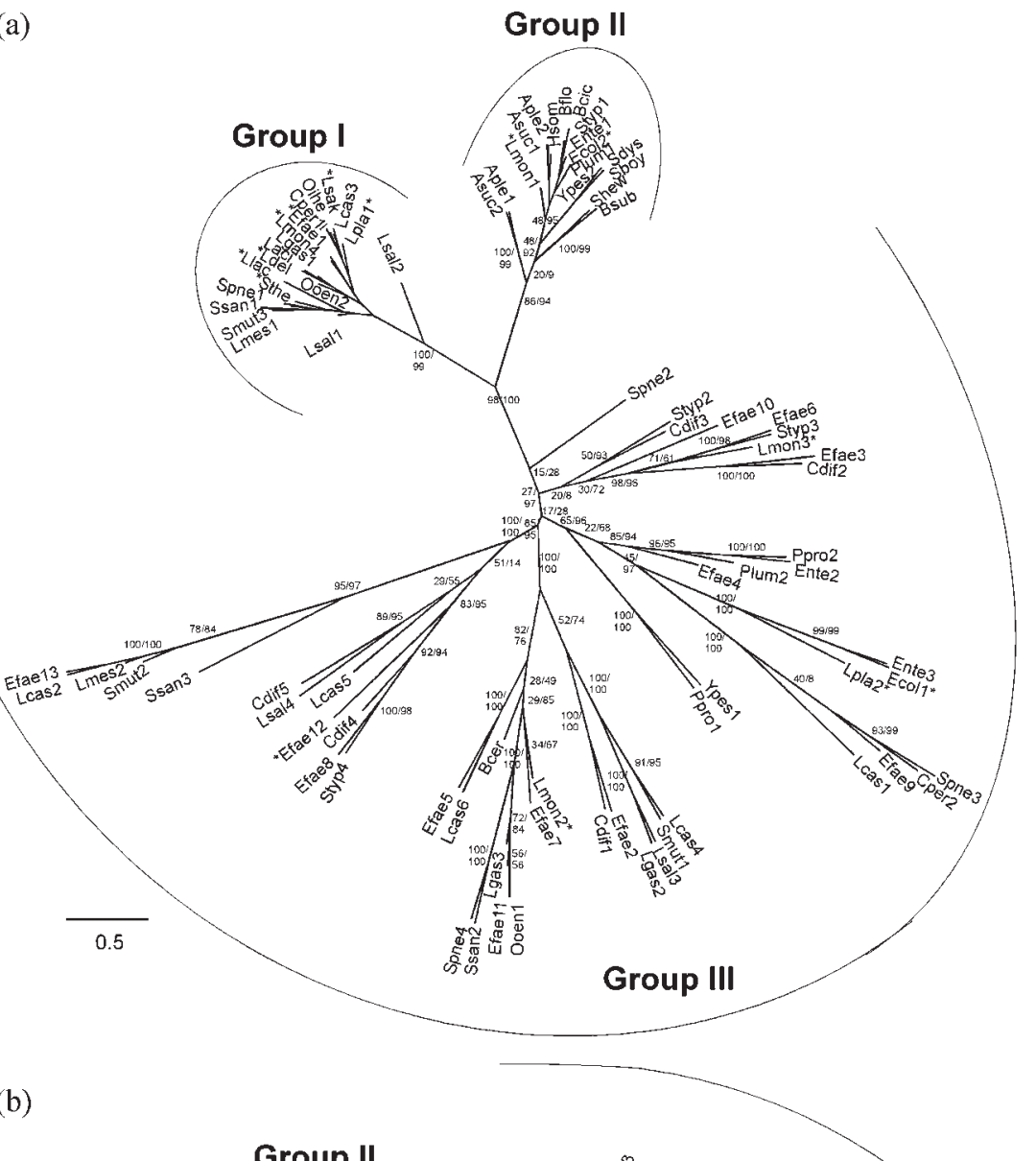

(b)

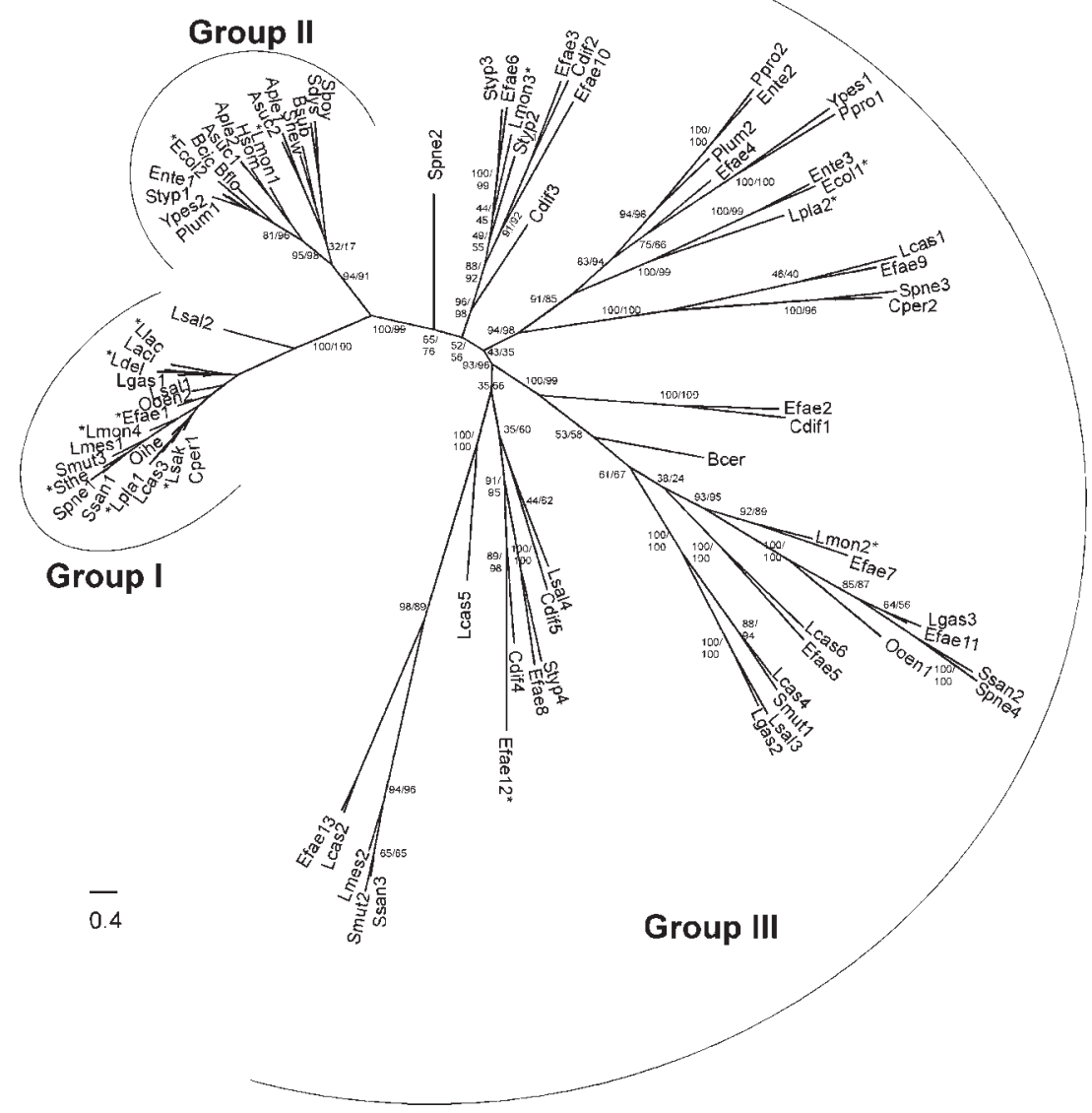


Fig. 1. Phylogenetic analysis of the man-PTS protein families IIC (a) and IID (b). Altogether, 86 protein pairs were analysed. The trees were constructed using the maximum-likelihood algorithm implemented in PhyML. Bootstrap values from 100 replicates (first value) and the aLRT branch support values (second value) are shown for most branches (some of the values are not shown due to space limitations). Asterisks indicate man-PTSs selected for the experimental analysis.

IIa and the class IIc bacteriocin lactococcin A, 14 different man-PTSs, distributed all over the phylogenetic tree, were selected for experimental analysis. These included all four man-PTSs from Li. monocytogenes (Lmon1-4), two (of 13) from Ent. faecalis (Efael and Efae12), two (of two) from Lb. plantarum (Lpla1-2), two (of two) from E. coli (Ecol12), and the single man-PTSs found in Lb. sakei (Lsak), Lc. lactis (Llac), Lb. delbrueckii (Ldel) and S. thermophilus (Sthe). The nisin-controlled expression (NICE) system (Kuipers et al., 1998) was used to express the individual man-PTS operons in an Lc. lactis mutant clone (B488) in which the single indigenous man-PTS locus in the genome has been deleted (Diep et al., 2007), thus containing no background man-PTS that might interfere with our bacteriocin receptor assays. The different homologous man-PTSs were first assessed for their ability to transport glucose in Lc. lactis by adding the non-metabolizable glucose analogue 2-deoxy-D-glucose (2-DG) to the growth medium (Thompson \& Chassy, 1982); growth inhibition with 2-DG is an indication of a functional man-PTS transporter. The results from the growth analysis, as summarized in Table 3, showed that all the man-PTSs of group I (Llac, Lsak, Efae1, Lmon4, Ldel, Sthe and Lpla1), in addition to Ecol2 (group II), can take up 2-DG when expressed in the heterologous host Lc. lactis. On the other hand, none of the remaining man-PTSs of group III (Lmon2, Lmon3, Ecol1, Lpla2 and Efae12) or Lmon1 (group II) was functional as a glucose transporter in $L c$. lactis, which suggests that these homologous transporters fulfil roles in the cells other than glucose transport (e.g. uptake of other sugars) or are not functional at all. Alternatively, these man-PTSs could be dependent on species-specific factors to be functional. It should be noted that a functional man-PTS in terms of sugar uptake is not a prerequisite for being a bacteriocin receptor, as we have previously shown that expression of the man-PTS IIC and IID genes in the absence of the man-PTS IIAB gene can provide a functional receptor (Diep et al., 2007).

To examine whether the expressed man-PTS genes could serve as bacteriocin receptors, all $14 \mathrm{Lc}$. lactis clones were challenged with four different class IIa bacteriocins, pediocin PA-1 (Marugg et al., 1992), enterocin P (Cintas et al., 2000), sakacin P (Tichaczek et al., 1994) and penocin A, (Diep et al., 2006) and one class IIc bacteriocin, lactococcin A (Holo et al., 1991). The MIC values determined by microtitre plate assays are given in Table 3 . In group I, six out of the seven selected man-PTSs were able to confer sensitivity to the class IIa bacteriocins but not to lactococcin A, while the last man-PTS from this

Table 3. Experimental analysis of selected man-PTS family members

\begin{tabular}{|c|c|c|c|c|c|c|c|c|}
\hline \multirow[t]{2}{*}{ Group } & \multirow[t]{2}{*}{ man-PTS (clone) } & \multicolumn{5}{|c|}{ MIC value $\left(B U \mathrm{ml}^{-1}\right)$ for bacteriocin } & \multirow[t]{2}{*}{ 2-DG inhibition $\dagger$} & \multirow[t]{2}{*}{ Genetic org. $\neq$} \\
\hline & & Ped PA-1 & EntP & SakP & PenA & $\operatorname{Lcn} A$ & & \\
\hline \multirow{4}{*}{ I } & Lpla1 (M127) & 35 & 25 & 140 & 30 & NI & + & AB-C-D \\
\hline & Lmon4 (M151) & 20 & 5 & $<0.5$ & 10 & NI & + & AB-C-D \\
\hline & Efael (M160) & 20 & 5 & 5 & 5 & NI & + & AB-C-D \\
\hline & Llac (B515) & NI & NI & NI & NI & 190 & + & AB-C-D \\
\hline \multirow[t]{2}{*}{ II } & Lmon1 (B148) & NI & NI & NI & NI & $\mathrm{NI}$ & - & A-B-C-D \\
\hline & Ecol2 (M130) & NI & $\mathrm{NI}$ & NI & NI & NI & + & AB-C-D \\
\hline \multirow[t]{2}{*}{ III } & Lmon2 (M149) & NI & NI & NI & NI & NI & - & A-B-C-D \\
\hline & Lmon3 (M150) & NI & NI & NI & NI & NI & - & A-i-B-C-D \\
\hline
\end{tabular}

${ }^{*}$ The numbers indicate the minimum concentrations (in $\mathrm{BU} \mathrm{ml}{ }^{-1}$ ) required to produce at least $50 \%$ growth inhibition. MIC values were determined at least twice with virtually the same results. NI, No inhibition observed at the highest bacteriocin concentration tested $\left(400 \mathrm{BU}^{-1}\right)$. $\dagger+$, Growth of the Lc. lactis clone was inhibited by 2-DG; -, no inhibition.

末Organization of the genes encoding the man-PTS subunits. Separated genes are indicated with hyphens. In Lmon3, an inserted gene (i) is found between the man-PTS IIA and IIB genes. 
group, the ptn operon from Lc. lactis (Llac), conferred sensitivity to lactococcin A but not to any of the class IIa bacteriocins. Of these, the man-PTSs Lsak (man operon), Lmon4 (mpt) and Efael (mpt) from Lb. sakei, Li. monocytogenes and Ent. faecalis, respectively, have previously been shown, in a direct or indirect manner, to be associated with sensitivity to bacteriocins (Dalet et al., 2001; Diep et al., 2007; Héchard et al., 2001), and we finally confirmed here that these man-PTSs indeed act as receptors for several class IIa bacteriocins. In addition, the group I man-PTS systems Lpla1 ( $p t s 9)$ from $L b$. plantarum, Ldel from Lb. delbrueckii and Sthe (man) from S. thermophilus were shown for the first time to function as receptors for bacteriocins. Remarkably, all selected members of groups II and III were unable to confer sensitivity to the different bacteriocins, except for Efae12 (from Ent. faecalis), which seemed to cause some sensitivity when the resulting clone was exposed to relatively high concentrations of sakacin P and penocin A (20- to 40-fold higher concentrations than for Efael, the other enterococcal manPTS tested). At present we cannot explain why Efae12 has this function, but as both Efael and Efae12 are derived from the same host (Ent. faecalis V583), the biological function of Efae12 as a bacteriocin receptor is probably insignificant, as it will be overshadowed by Efae1.

Out of the 14 man-PTSs selected, only the lactococcal Llac of group I could function as a receptor for the class IIc bacteriocin lactococcin A. This lactococcal species-specificity, noticed more than 15 years ago (Henderson et al., 1992; Holo et al., 1991; Kok et al., 1993), that lactococcins A and B only target lactococcal species, while pediocin-like bacteriocins do not target these species, can now be ascribed to differences in the amino acid sequences of the IIC and IID subunits of their man-PTSs.

Notably, the selected bacteriocins seemed to differ greatly from each other in their potency in targeting the various man-PTSs. While pediocin PA-1 appeared to target all non-lactococcal receptors (from group I) with a similar range of efficiency (i.e. having only a fivefold difference between the highest and the lowest), a significantly larger variation was seen for the other bacteriocins; the difference between the highest and the lowest was about 19-fold for enterocin $\mathrm{P}, 280$-fold for sakacin $\mathrm{P}$ and 10 -fold for penocin A. Two of the man-PTSs, Lmon4 and Efael, were the most active receptors for all four bacteriocins, and not surprisingly, these two systems are most closely related to each other according to the phylogenetic trees (Fig. 1). This correlation became even more evident in a separate phylogenetic analysis of concatenated IIC and IID proteins from 31 group I man-PTSs (including 12 man-PTSs that were left out of the first phylogenetic analysis due to space limitations), in which receptors conferring high, medium and low sensitivity appeared to be organized into distinct domains (Fig. 2). For instance, Lsak and Lpla1, both conferring medium sensitivity, are located next to each other within a domain, and both are well separated from the domain that contains the highly efficient receptors
Lmon4 and Efael. Similarly, Sthe, which confers low sensitivity, is defined within another domain. These results are in line with previous comparative analyses of the inhibitory spectra of class IIa bacteriocins: (i) species of Enterococcus, Listeria and Carnobacterium are highly sensitive to pediocin-like bacteriocins (low MIC values); (ii) species of Lactobacillus, Pediococcus and Clostridium are also frequently inhibited by these bacteriocins, although they are often less sensitive (higher MIC values); and (iii) strains of Streptococcus and Leuconostoc are occasionally reported to be sensitive to class IIa bacteriocins at a low level (very high MIC values) (Diep et al., 2006; Eijsink et al., 1998).

It is also worth noting that the in silico analysis of manPTSs also revealed an interesting link between man-PTS receptors and bacteriocin producers. From the available sequence information, all bacterial species producing class IIa bacteriocins (Drider et al., 2006; Fimland et al., 2005) seem to have genes encoding a man-PTS belonging to phylogenetic group I. For example, Bacillus coagulans is the only Bacillus species known to produce a pediocin-like bacteriocin (Le Marrec et al., 2000), and B. coagulans is also the only Bacillus species harbouring a group I man-PTS. This notion implies that there is an evolutionary link between the production of class IIa bacteriocins and the presence of a group I man-PTS in the same cell, although the biological significance of this observation has yet to be understood.

\section{Group I receptors contain three distinct regions in their sequences}

Given that the receptor function of a man-PTS is related to its phylogenetic position (Figs 1 and 2), we looked for important sequence differences between the different manPTSs that might be responsible for the observed variation in receptor potency. Multiple sequence alignments of the 14 man-PTSs used in the experimental analysis revealed at least three regions in the IIC and IID proteins, termed region- $\alpha$, region- $\beta$ and region- $\gamma$, that clearly distinguish IIC and IID proteins with good receptor function from those with poor or no receptor function (Fig. 3 and Supplementary Fig. S1). Region- $\alpha$, which is located in the $\mathrm{N}$-terminal half of IIC of group I, is characterized by several conserved residues and an additional sequence stretch (3-4 aa); this region contains the conserved sequence GGQGXXG in the man-PTSs belonging to the high- and medium-sensitivity group, while a related motif (GG[D/K]FXXXG) is found in the man-PTSs with low sensitivity. Interestingly, Llac, which confers sensitivity only to the class IIc lactococcin A but not to class IIa bacteriocins, lacks such a sequence, suggesting that the motif in region- $\alpha$ is important for interaction with class IIa bacteriocins only. Region- $\beta$, which is located at the Cterminal end of the IIC proteins, is characterized for group I man-PTSs by an enrichment in glycine residues and the presence of a conserved sequence DP[I/L/V]GDI[I/L][D/E/ 


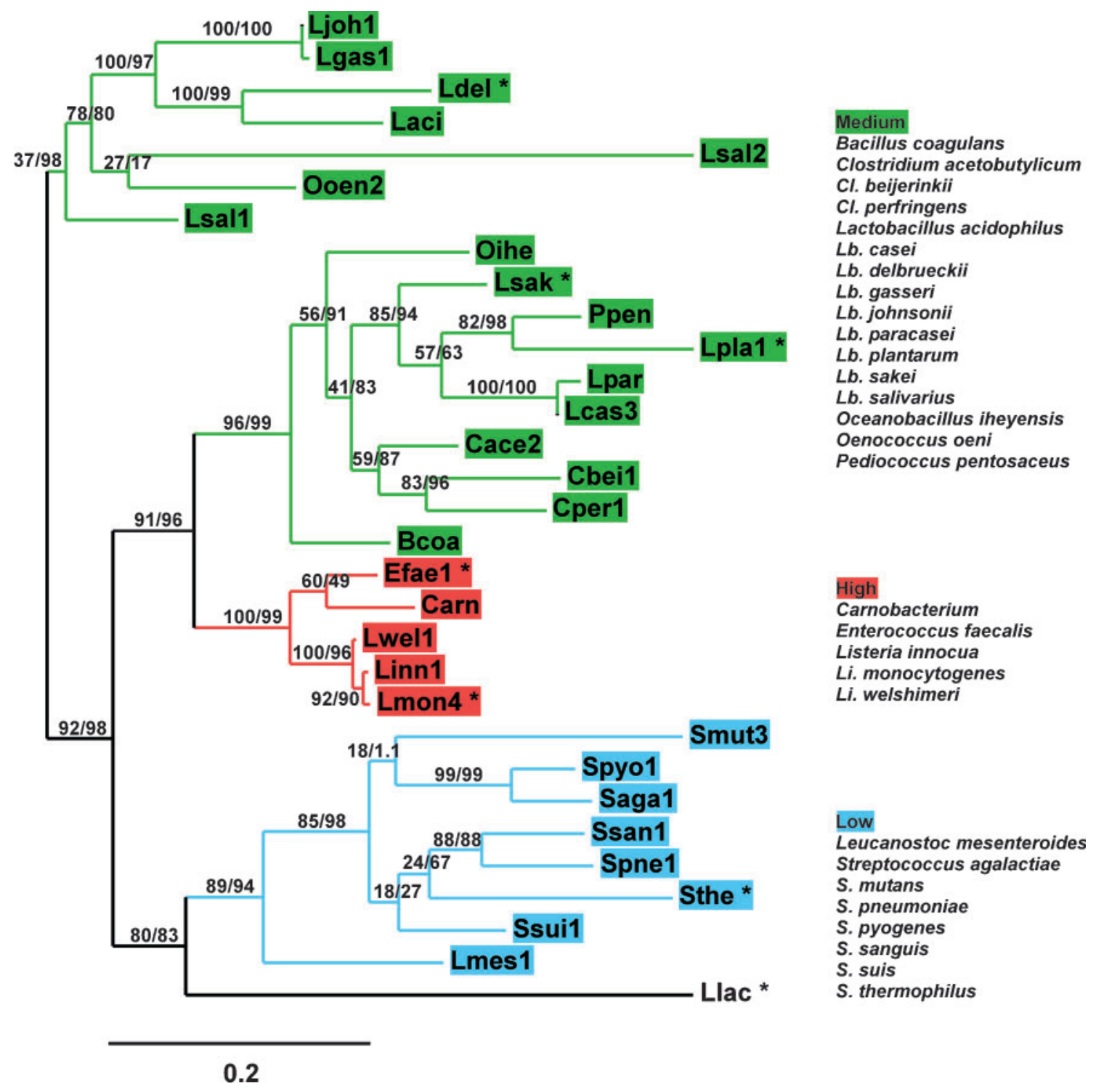

Fig. 2. Phylogenetic clustering of concatenated man-PTS IIC and IID proteins from group I using the maximum-likelihood algorithm in PhyML. Bootstrap support values from 100 replicates (first value) and aLRT branch support values (second value) are shown. The man-PTSs are separated into high- (red), medium- (green) and low-sensitivity (blue) groups based on the receptor potency. Asterisks indicate man-PTSs included in the experimental analysis. The bacterial species carrying these proteins are listed.

$\mathrm{N}] \mathrm{XY}$, in which P, I and Y are unique to group I man-PTS. Finally, region- $\gamma$ designates a location in the IID proteins in which members of phylogenetic group I contain an additional sequence of 35-40 aa which is absent in their counterparts from groups II and III. Interestingly, transmembrane prediction of the IIC and IID proteins using the TMHMM Server 2.0 (Krogh et al., 2001) suggested that all these three regions discussed here are located on the extracellular side of the membrane, and thus might serve as binding sites for bacteriocins on the surface of sensitive cells.
The fact that two of these distinct regions are located in IIC and the last one in IID suggests that the bacteriocin binding site(s) on the receptor are composed of sequences from different proteins. This notion is in line with our recent study (Diep et al., 2007), which showed that expression of individual IIC or IID genes derived from a potent manPTS (such as Lsak or Llac) could not confer sensitivity. Furthermore, we have also found that, while the pairwise IIC and IID from Lsak and Llac are very potent receptors for pediocin-like bacteriocins and lactococcin $\mathrm{A}$, respectively, the combination of one component from one system 


\section{IIC-proteins}

3 - Efae12
3 - Lpla2
3 - Ecol1
2 - Lmon1
2 - Ecol2
1 - Llac
1 - Ldel
1 - Sthe
1 - Lmon4
1 - Efae1
1 - Lsak
1 - Lpla1
3 - Lmon2
3 - Lmon3

$81-$
$77-$
$78-$
$75-$
$77-$
$77-$
$77-$
$78-$
$75-$
$75-$
$77-$
$77-$
$77-$
$76-$

Region- $\alpha$

AAAIAVPVALIGNL----KP-EAAIAVAVP - 104 AGIMTVVLAYTTGK----TP-STAIGLALP - 100 AGLMTTVIAWSTGV----DA-KTAIGLGLP - 101 ASIISTILVITGGQ----DI-SVGISLAIP - 98 ASIISTILVIAGHQ----SI-GAGIALAIP - 100 ASIASSILMVOSNNFDLTHIMGTIVPAAIL - 105 AAVASAIILIKGGQ-GTKGI-GTATGLAIT - 103 ASVAAAI I LVKGGKFTAEGI-GVAIAIAIL - 105 ASVASAIILVLGGQ-GVAGI -PSAIAIAIP - 101 ASVASAI I LVLGGQ-GVKGV-PSAIAIAVP - 101 AS IASAIILVLGGQ-GKAGV-TSAIAIAVP - 103 AAIASAIILVLGGQ-GRAGV-SSAIAIAVP - 103 GAIVGTVFAVLSGQ----DA-EFAIGLAIP - 100 GSILGTAFAISTGE----ST-AVALALGIP - 99
Region- $\beta$

246 - FVQVQKGKPVA---ESAGSASATT---DFDDDDDYDDGF - 278 238 - EFYHNKK------QTDNEKKLKSMIESASGNGDDGDGI - 269 237 - YEFFNAKS------RQQAQPQPVA---SKNEEEDYSNGI - 267 236 - YIQLNPKYQLKEAIQQYGGGGGGR---SADDLDDDLDD- -270 237 - YIQLSPKYN-----RVAGAPAQAA---GNNDLDNELD- - - 266 236- YLNLQAS-------GESENGTASS---SGDPIGDILNDY - 270 234 - YLALEEKVS-----KCSCDVAAA ---TGDPLGDIIDDY - 270 236 - YLNLSKQGG-----GNGGGNGGGTSSESGDPIGDILEDY - 275 232 - YLNLSKMGG-----GNSNGGGGGN---SRDPLGDILNDY - 268 232 - YLNLSKMG------ GSSNSNGGGN---SGDPLGDILNDY - 267 234 - YLALSKQ-------GS GNNGGGSN---TGDPLGDIIDNY - 268 234 - YLNLSKM-------GCSGNGGCSN---TGDPVGDIIDKY - 268 231 - YEKQNFKN------PVAACANCAALVCEENEDGEYED-- - 267 238- YATLKNDNG-----PKNTNTEPALANDGGINYED--EEF $\quad-272$

\section{IID-proteins}

$\begin{array}{ll}3 \text { - Efae12 } & 21 \\ 3 \text { - Lmon2 } & 200 \\ 3 \text { - Ecol1 } & 187 \\ 3 \text { - Lpla2 } & 19 \\ 3 \text { - Lmon3 } & 199 \\ \text { 2 - Lmon1 } & 201 \\ 2 \text { - Ecol2 } & 201 \\ \text { 1 - Ldel } & 196 \\ \text { 1 - Sthe } & 195 \\ \text { 1 - Llac } & 196 \\ \text { 1 - Lpla1 } & 196 \\ \text { 1 - Lsak } & 195 \\ \text { 1 - Lmon4 } & 195 \\ \text { 1 - Efae1 } & 195\end{array}$

\begin{tabular}{|c|c|c|}
\hline & Region- $\gamma$ & \\
\hline $16-$ & & -241 \\
\hline & ------------- LKMQDMLDQIMP & -225 \\
\hline 37 - & ------------- HSVALQQDFFDDKVF & -214 \\
\hline $95-$ & IAV-----KTKIPVSAG----------- & -222 \\
\hline & ------------ VTIQSVFDGIVP & -224 \\
\hline 01 - & ------------ KDVPTT & -233 \\
\hline 01 - & G-----------------------------KEHVTTV & -236 \\
\hline $196-$ & PPIQKGGYIDWNKLPSGAAGIKEALTQQADGRSLTNTKVTTI & -256 \\
\hline 195 - & KGAYIEWPKGYVTGDQLKTILGQVNDKLSFDKIQVDTI & -255 \\
\hline 196 - & AYLEFPKGSVSGTQLHDILGQVGNKLSLDPTKVTYI & -259 \\
\hline 196 - & KGAAGIKEALTQQAAGRSLDKYKVTTLQDNLNQLIP & -257 \\
\hline 195 - & LIP & -255 \\
\hline & $-\mathrm{P}$ & - \\
\hline & & \\
\hline
\end{tabular}

Fig. 3. Multiple sequence alignments of the IIC and IID proteins from the 14 man-PTSs used in the experimental analysis. Shown here are three regions which clearly separate group I from group II and III sequences: region- $\alpha$ in the N-terminal half of IIC (residues in the putative GGQGXXG motif are highlighted with a black background), region- $\beta$ in the C-terminal end of IIC (the glycine-rich region is indicated by a grey background, and residues that are conserved only in group I man-PTSs are shown with a black background) and region- $\gamma$ in the C-terminal half of IID. The number in front of the man-PTS names indicates the phylogenetic group $(1,2$ or 3$)$, and the numbers next to the sequences indicate amino acid positions in each protein. Alignments of region- $\alpha$, region- $\beta$ and region- $\gamma$, including all 86 IIC and IID proteins used in the phylogenetic analysis, can be found in Supplementary Fig. S1. The alignment was constructed using MUSCLE.

with a non-cognate partner from another system leads to little or no sensitivity to either type of bacteriocin (data not shown). As the pairwise IIC and IID proteins seem to have evolved in a parallel manner (Fig. 1), creation of such hybrids from two phylogenetically divergent subunits probably forms a complex that has become defective for bacteriocin binding. However, we cannot exclude the possibility that the bacteriocin binding site is located in one subunit but that its functionality needs to be stabilized by the presence of the cognate partner. It should also be mentioned that region- $\gamma$ in IID has previously been associated with sensitivity to class IIa bacteriocins, because an in-frame deletion of this region in $m p t D$ renders $L i$. monocytogenes EGD-e cells resistant to mesentericin Y105 (Dalet et al., 2001). However, it is not known whether region- $\gamma$ is directly involved in the interaction with the bacteriocin, or whether this deletion perturbs the structure of MptD. Intragenic and intergenic chimeric receptors designed to address the nature of the bacteriocin receptorspecificity, and the role of region- $\alpha$, region- $\beta$ and region- $\gamma$ in this context, are currently under investigation.

\section{Differential expression of man-PTS causes variation in bacteriocin sensitivity}

It has been frequently observed that different strains of the same bacterial species can vary greatly in sensitivity to a given bacteriocin (Eijsink et al., 1998; Katla et al., 2003). In most cases, the reason for this variation is not known. For instance, Lb. sakei strains 23K, Lb790 and LMGT 2313 display a great variation in sensitivity toward pediocin PA-1, with LMGT 2313 being the most sensitive (Fig. 4a). By DNA sequencing, all three strains were found to harbour almost identical manPTS genes in their genomes (except for a few silent mutations in the DNA sequences that have no effect on the amino acid sequences). Furthermore, subcloning of the man-PTSs of $L b$. sakei 23K, Lb790 and LMGT 2313 in the man-PTS-free strain Lc. lactis $\mathrm{B} 488$ showed that all three clones display more or less the same degree of sensitivity to pediocin PA-1 (Fig. 4b), illustrating that these silent mutations do not account for the observed variation in sensitivity.

To examine whether the variation in sensitivity among these strains could be due to differential gene expression, 

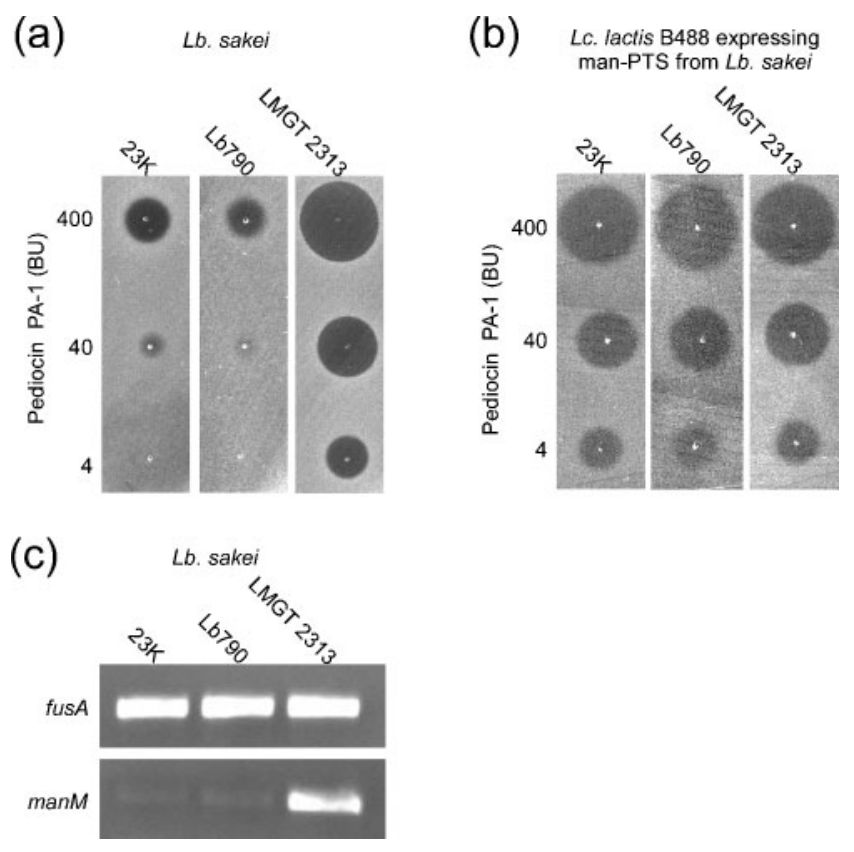

Fig. 4. Variation in bacteriocin sensitivity is due to differential expression levels of the man-PTS. Soft agar overlay assay with the three Lb. sakei strains 23K, Lb790 and LMGT 2313 (a), and with the three Lc. lactis clones expressing the man-PTSs derived from the $L b$. sakei strains (b). Cells were challenged with $5 \mu$ of three different concentrations of pediocin PA-1 (400, 40 and $4 \mathrm{BU})$ and inhibition is seen as clear zones. (c) RT-PCR analysis of manM (encoding the man-PTS IIC component) in the $L b$. sakei strains. The housekeeping gene fus $A$ (encoding the translation elongation factor EF-G) was included as a control.

the relative transcription levels of manM (encoding the receptor IIC subunit) in the three $L b$. sakei strains were determined by RT-PCR (Fig. 4c). These results clearly indicate that the man $M$ expression levels are higher in the more sensitive strain LMGT 2313 than in 23K and Lb790. Thus, the three $L b$. sakei strains harbouring the same manPTSs displayed highly variable sensitivity to pediocin PA-1 because of differential expression levels of their man-PTS genes. This is in line with previous observations, which show that genes involved in the regulation of man-PTS expression, such as rpoN (encoding a $\sigma^{54}$ subunit of RNA polymerase) and $m p t R / \operatorname{man} R$ (encoding $\sigma^{54}$-associated transcription factors), influence sensitivity to the pediocin-like bacteriocin mesentericin Y105 in Ent. faecalis and Li. monocytogenes (Dalet et al., 2000, 2001; Héchard et al., 2001). In addition, it should also be kept in mind that other strain-specific factors, including cell-surface differences (Vadyvaloo et al., 2002, 2004) and relics of bacteriocin loci containing immunity genes (Moretro et al., 2005), can be responsible for the observed variability in bacteriocin sensitivity between strains from the same bacterial species.

\section{Concluding remarks}

Class IIa bacteriocins are considered promising antimicrobial agents for use in medicine and food preservation. Most studies performed hitherto have been conducted by assaying the susceptibility of randomly selected bacterial strains to various bacteriocins, and these results are often difficult to compare due to variations in growth conditions (of both the bacteriocin producer and the indicator strain), bacteriocin assays and choice of indicator strains. The present work provides a systematic overview of the functionality of receptors for pediocin-like bacteriocins, showing that only one subgroup of man-PTS proteins are efficient receptors. The results highlight the great potential of these bacteriocins to improve therapeutic strategies, in particular against enterococcal and listerial infections. Variation in receptor sequences seems to account for much of the variation in bacteriocin susceptibility between different bacterial species, and we have identified three sequence regions that clearly distinguish man-PTSs that could serve as bacteriocin receptors from those that could not. Whether these three sequence regions are directly involved in the bacteriocin binding sites awaits further investigation. In addition, other factors such as gene expression level also seem to be of high importance in determining the degree of sensitivity of a strain.

\section{ACKNOWLEDGEMENTS}

This work was supported by grants from the Research Council of Norway. We would like to thank Emma Lundman for critical reading of the manuscript.

\section{REFERENCES}

Anisimova, M. \& Gascuel, O. (2006). Approximate likelihood-ratio test for branches: a fast, accurate, and powerful alternative. Syst Biol 55, 539-552.

Arous, S., Dalet, K. \& Héchard, Y. (2004). Involvement of the mpo operon in resistance to class IIa bacteriocins in Listeria monocytogenes. FEMS Microbiol Lett 238, 37-41.

Bolotin, A., Quinquis, B., Renault, P., Sorokin, A., Ehrlich, S. D., Kulakauskas, S., Lapidus, A., Goltsman, E., Mazur, M. \& other authors (2004). Complete sequence and comparative genome analysis of the dairy bacterium Streptococcus thermophilus. Nat Biotechnol 22, 1554-1558.

Brotz, H., Josten, M., Wiedemann, I., Schneider, U., Gotz, F., Bierbaum, G. \& Sahl, H. G. (1998). Role of lipid-bound peptidoglycan precursors in the formation of pores by nisin, epidermin and other lantibiotics. Mol Microbiol 30, 317-327.

Chaillou, S., Champomier-Verges, M. C., Cornet, M., Crutz-Le Coq, A. M., Dudez, A. M., Martin, V., Beaufils, S., Darbon-Rongere, E., Bossy, R. \& other authors (2005). The complete genome sequence of the meat-borne lactic acid bacterium Lactobacillus sakei 23K. Nat Biotechnol 23, 1527-1533.

Chevenet, F., Brun, C., Banuls, A. L., Jacq, B. \& Christen, R. (2006). TreeDyn: towards dynamic graphics and annotations for analyses of trees. BMC Bioinformatics 7, 439. 
Chopin, A., Chopin, M. C., Moillo-Batt, A. \& Langella, P. (1984). Two plasmid-determined restriction and modification systems in Streptococcus lactis. Plasmid 11, 260-263.

Cintas, L. M., Casaus, P., Herranz, C., Havarstein, L. S., Holo, H., Hernandez, P. E. \& Nes, I. F. (2000). Biochemical and genetic evidence that Enterococcus faecium L50 produces enterocins L50A and L50B, the sec-dependent enterocin $\mathrm{P}$, and a novel bacteriocin secreted without an N-terminal extension termed enterocin Q. J Bacteriol 182, 6806-6814.

Dalet, K., Briand, C., Cenatiempo, Y. \& Héchard, Y. (2000). The rpoN gene of Enterococcus faecalis directs sensitivity to subclass IIa bacteriocins. Curr Microbiol 41, 441-443.

Dalet, K., Cenatiempo, Y., Cossart, P. \& Héchard, Y. (2001). A $\sigma^{54}$ dependent PTS permease of the mannose family is responsible for sensitivity of Listeria monocytogenes to mesentericin Y105. Microbiology 147, 3263-3269.

Dereeper, A., Guignon, V., Blanc, G., Audic, S., Buffet, S., Chevenet, F., Dufayard, J. F., Guindon, S., Lefort, V. \& other authors (2008). Phylogeny.fr: robust phylogenetic analysis for the non-specialist. Nucleic Acids Res 36, W465-W469.

de Ruyter, P. G., Kuipers, O. P. \& de Vos, W. M. (1996). Controlled gene expression systems for Lactococcus lactis with the food-grade inducer nisin. Appl Environ Microbiol 62, 3662-3667.

Deutscher, J., Francke, C. \& Postma, P. W. (2006). How phosphotransferase system-related protein phosphorylation regulates carbohydrate metabolism in bacteria. Microbiol Mol Biol Rev 70, 939-1031.

Diep, D. B., Godager, L., Brede, D. \& Nes, I. F. (2006). Data mining and characterization of a novel pediocin-like bacteriocin system from the genome of Pediococcus pentosaceus ATCC 25745. Microbiology 152, 1649-1659.

Diep, D. B., Skaugen, M., Salehian, Z., Holo, H. \& Nes, I. F. (2007). Common mechanisms of target cell recognition and immunity for class II bacteriocins. Proc Natl Acad Sci U S A 104, 2384-2389.

Drider, D., Fimland, G., Héchard, Y., McMullen, L. M. \& Prévost, H. (2006). The continuing story of class IIa bacteriocins. Microbiol Mol Biol Rev 70, 564-582.

Edgar, R. C. (2004). MUSCLE: multiple sequence alignment with high accuracy and high throughput. Nucleic Acids Res 32, 1792-1797.

Eijsink, V. G. H., Skeie, M., Middelhoven, P. H., Brurberg, M. B. \& Nes, I. F. (1998). Comparative studies of class IIa bacteriocins of lactic acid bacteria. Appl Environ Microbiol 64, 3275-3281.

Fimland, G., Johnsen, L., Dalhus, B. \& Nissen-Meyer, J. (2005). Pediocin-like antimicrobial peptides (class IIa bacteriocins) and their immunity proteins: biosynthesis, structure, and mode of action. J Pept Sci 11, 688-696.

Glaser, P., Frangeul, L., Buchrieser, C., Rusniok, C., Amend, A., Baquero, F., Berche, P., Bloecker, H., Brandt, P. \& other authors (2001). Comparative genomics of Listeria species. Science 294, 849-852.

Gravesen, A., Ramnath, M., Rechinger, K. B., Andersen, N., Jansch, L., Héchard, Y., Hastings, J. W. \& Knochel, S. (2002). High-level resistance to class IIa bacteriocins is associated with one general mechanism in Listeria monocytogenes. Microbiology 148, 2361-2369.

Guindon, S. \& Gascuel, O. (2003). A simple, fast, and accurate algorithm to estimate large phylogenies by maximum likelihood. Syst Biol 52, 696-704.

Héchard, Y., Pelletier, C., Cenatiempo, Y. \& Frère, J. (2001). Analysis of $\sigma^{54}$-dependent genes in Enterococcus faecalis: a mannose PTS permease (EII ${ }^{\text {Man }}$ ) is involved in sensitivity to a bacteriocin, mesentericin Y105. Microbiology 147, 1575-1580.
Henderson, J. T., Chopko, A. L. \& van Wassenaar, P. D. (1992). Purification and primary structure of pediocin PA-1 produced by Pediococcus acidilactici PAC-1.0. Arch Biochem Biophys 295, 5-12.

Higuchi, R. (1990). Recombinant PCR. In PCR Protocols: a Guide to Methods and Applications, pp. 177-183. Edited by M. L. Innes, D. H. Gelfand, J. J. Sninsky \& T. J. White. San Diego: Academic Press.

Holo, H. \& Nes, I. F. (1989). High-frequency transformation, by electroporation, of Lactococcus lactis subsp. cremoris grown with glycine in osmotically stabilized media. Appl Environ Microbiol 55, 3119-3123.

Holo, H., Nilssen, O. \& Nes, I. F. (1991). Lactococcin A, a new bacteriocin from Lactococcus lactis subsp. cremoris: isolation and characterization of the protein and its gene. J Bacteriol 173, 3879-3887.

Katla, T., Naterstad, K., Vancanneyt, M., Swings, J. \& Axelsson, L. (2003). Differences in susceptibility of Listeria monocytogenes strains to sakacin P, sakacin A, pediocin PA-1, and nisin. Appl Environ Microbiol 69, 4431-4437.

Kleerebezem, M., Beerthuyzen, M. M., Vaughan, E. E., de Vos, W. M. \& Kuipers, O. P. (1997). Controlled gene expression systems for lactic acid bacteria: transferable nisin-inducible expression cassettes for Lactococcus, Leuconostoc, and Lactobacillus spp. Appl Environ Microbiol 63, 4581-4584.

Kleerebezem, M., Boekhorst, J., van Kranenburg, R., Molenaar, D., Kuipers, O. P., Leer, R., Tarchini, R., Peters, S. A., Sandbrink, H. M. \& other authors (2003). Complete genome sequence of Lactobacillus plantarum WCFS1. Proc Natl Acad Sci U S A 100, 1990-1995.

Kok, J., Holo, H., van Belkum, M. J., Haandrikman, A. J. \& Nes, I. F. (1993). Nonnisin bacteriocins in lactococci: biochemistry, genetics, and mode of action. In Bacteriocins of Lactic Acid Bacteria, pp. 121150. Edited by D. G. Hoover \& L. R. Steenson. San Diego: Academic Press.

Krogh, A., Larsson, B., von Heijne, G. \& Sonnhammer, E. L. (2001). Predicting transmembrane protein topology with a hidden Markov model: application to complete genomes. J Mol Biol 305, 567-580.

Kuipers, O. P., de Ruyter, P. G. G. A., Kleerebezem, M. \& de Vos, W. M. (1998). Quorum sensing-controlled gene expression in lactic acid bacteria. J Biotechnol 64, 15-21.

Lauret, R., Morel-Deville, F., Berthier, F., Champomier-Verges, M., Postma, P., Ehrlich, S. D. \& Zagorec, M. (1996). Carbohydrate utilization in Lactobacillus sake. Appl Environ Microbiol 62, 19221927.

Le Marrec, C., Hyronimus, B., Bressollier, P., Verneuil, B. \& Urdaci, M. C. (2000). Biochemical and genetic characterization of coagulin, a new antilisterial bacteriocin in the pediocin family of bacteriocins, produced by Bacillus coagulans $\mathrm{I}_{4}$. Appl Environ Microbiol 66, 52135220.

Martinez, B., Bottiger, T., Schneider, T., Rodriguez, A., Sahl, H. G. \& Wiedemann, I. (2008). Specific interaction of the unmodified bacteriocin lactococcin 972 with the cell wall precursor lipid II. Appl Environ Microbiol 74, 4666-4670.

Marugg, J. D., Gonzalez, C. F., Kunka, B. S., Ledeboer, A. M., Pucci, M. J., Toonen, M. Y., Walker, S. A., Zoetmulder, L. C. \& Vandenbergh, P. A. (1992). Cloning, expression, and nucleotide sequence of genes involved in production of pediocin PA-1, and bacteriocin from Pediococcus acidilactici PAC1.0. Appl Environ Microbiol 58, 2360-2367.

Moretro, T., Naterstad, K., Wang, E., Aasen, I. M., Chaillou, S., Zagorec, M. \& Axelsson, L. (2005). Sakacin P non-producing Lactobacillus sakei strains contain homologues of the sakacin $\mathrm{P}$ gene cluster. Res Microbiol 156, 949-960.

Nes, I. F., Diep, D. B., Havarstein, L. S., Brurberg, M. B., Eijsink, V. \& Holo, H. (1996). Biosynthesis of bacteriocins in lactic acid bacteria. Antonie Van Leeuwenhoek 70, 113-128. 
Nes, I. F., Yoon, S.-S. \& Diep, D. B. (2007). Ribosomally synthesized antimicrobial peptides (bacteriocins) in lactic acid bacteria: a review. Food Sci Biotechnol 16, 675-690.

Nieto Lozano, J. C., Meyer, J. N., Sletten, K., Pelaz, C. \& Nes, I. F. (1992). Purification and amino acid sequence of a bacteriocin produced by Pediococcus acidilactici. J Gen Microbiol 138, 1985-1990.

Nissen-Meyer, J., Rogne, P., Oppegard, C., Haugen, H. S. \& Kristiansen, P. E. (2009). Structure-function relationships of the non-lanthionine-containing peptide (class II) bacteriocins produced by Gram-positive bacteria. Curr Pharm Biotechnol 10, 19-37.

Postma, P. W., Lengeler, J. W. \& Jacobson, G. R. (1993). Phosphoenolpyruvate: carbohydrate phosphotransferase systems of bacteria. Microbiol Rev 57, 543-594.

Ramnath, M., Beukes, M., Tamura, K. \& Hastings, J. W. (2000). Absence of a putative mannose-specific phosphotransferase system enzyme IIAB component in a leucocin A-resistant strain of Listeria monocytogenes, as shown by two-dimensional sodium dodecyl sulfatepolyacrylamide gel electrophoresis. Appl Environ Microbiol 66, 30983101.

Ramnath, M., Arous, S., Gravesen, A., Hastings, J. W. \& Héchard, Y. (2004). Expression of mptC of Listeria monocytogenes induces sensitivity to class IIa bacteriocins in Lactococcus lactis. Microbiology 150, 2663-2668.

Sahm, D. F., Kissinger, J., Gilmore, M. S., Murray, P. R., Mulder, R., Solliday, J. \& Clarke, B. (1989). In vitro susceptibility studies of vancomycin-resistant Enterococcus faecalis. Antimicrob Agents Chemother 33, 1588-1591.

Schillinger, U. \& Lucke, F. K. (1989). Antibacterial activity of Lactobacillus sake isolated from meat. Appl Environ Microbiol 55, 1901-1906.
Thompson, J. \& Chassy, B. M. (1982). Novel phosphoenolpyruvatedependent futile cycle in Streptococcus lactis: 2-deoxy-D-glucose uncouples energy production from growth. J Bacteriol 151, 14541465.

Tichaczek, P. S., Nissen-Meyer, J., Nes, I. F., Vogel, R. F. \& Hammes, W. (1992). Characterization of the bacteriocins curvacin A from Lactobacillus curvatus LTH1174 and sakacin P from L. sake LTH673. Syst Appl Microbiol 15, 460-468.

Tichaczek, P. S., Vogel, R. F. \& Hammes, W. P. (1994). Cloning and sequencing of sakP encoding sakacin $\mathrm{P}$, the bacteriocin produced by Lactobacillus sake LTH 673. Microbiology 140, 361-367.

Vadyvaloo, V., Hastings, J. W., van der Merwe, M. J. \& Rautenbach, M. (2002). Membranes of class IIa bacteriocin-resistant Listeria monocytogenes cells contain increased levels of desaturated and short-acylchain phosphatidylglycerols. Appl Environ Microbiol 68, 5223-5230.

Vadyvaloo, V., Arous, S., Gravesen, A., Héchard, Y., ChauhanHaubrock, R., Hastings, J. W. \& Rautenbach, M. (2004). Cell-surface alterations in class IIa bacteriocin-resistant Listeria monocytogenes strains. Microbiology 150, 3025-3033.

Wiedemann, I., Breukink, E., van Kraaij, C., Kuipers, O. P., Bierbaum, G., de Kruijff, B. \& Sahl, H. G. (2001). Specific binding of nisin to the peptidoglycan precursor lipid II combines pore formation and inhibition of cell wall biosynthesis for potent antibiotic activity. J Biol Chem 276, 1772-1779.

Zúñiga, M., Comas, I., Linaje, R., Monedero, V., Yebra, M. J., Esteban, C. D., Deutscher, J., Perez-Martinez, G. \& Gonzalez-Candelas, F. (2005). Horizontal gene transfer in the molecular evolution of mannose PTS transporters. Mol Biol Evol 22, 1673-1685.

Edited by: D. M. Gordon 